Detrital zircon in a supercontinental setting: Locally derived and fartransported components in the Ordovician Natal Group, South Africa

\author{
M. Kristoffersen ${ }^{1 *}$, T. Andersen ${ }^{1,2}$, M. A. Elburg ${ }^{2}$ \& M. K. Watkeys ${ }^{3}$ \\ ${ }^{1}$ Department of Geosciences, University of Oslo, PO Box 1047 Blindern, N-0316 Oslo, \\ Norway \\ ${ }^{2}$ Department of Geology, University of Johannesburg, PO Box 524, Auckland Park 2006, \\ South Africa \\ ${ }^{3}$ Discipline of Geological Sciences, School of Agricultural, Earth and Environmental \\ Sciences, University of KwaZulu-Natal, South Africa \\ *Corresponding author (email: magnus.kristoffersen@geo.uio.no)
}

Words total 10353, words in main text: 5232

103 references

9 figures

7 tables

Supplementary material: U-Pb and Lu-Hf data

Running title: Detrital zircon Natal Group 
Abstract: U-Pb and Lu-Hf signatures of detrital zircon from conglomerates and sandstones of the Ordovician Natal Group, South Africa were determined using LA-ICPMS. The basal conglomerates are dominated by Palaeo- to Mesoarchaean detrital zircon with $\varepsilon_{\mathrm{Hf}}$-values from +3 to -4 with minor Mesoproterozoic input, indicating a proximal source in the Kaapvaal Craton and minor input from rocks of the Natal Sector of the Mesoproterozoic NamaquaNatal province. The sandstones are all dominated by a combination of juvenile Mesoproterozoic zircon and Neoproterozoic zircon derived from Mesoproterozoic rocks that were reworked during the Pan-African Orogeny. Several sedimentary sequences from former Gondwana with Neoproterozoic to Permian depositional ages show similar detrital zircon signatures. Sedimentary sequences of such vast temporal and geographical distribution are unlikely to have been fed by a single source, making it more likely that these sequences were fed by several different (Pan-Gondwana) source terranes with closely similar U-Pb and Lu-Hf zircon signatures. The results show that source terrane non-uniqueness can make ascertaining sedimentary provenance from detrital zircon impossible, and should be taken as a reminder when using detrital zircon as evidence for far reaching conclusions in basin evolution studies and palaeogeography.

Supplementary material: $\mathrm{U}-\mathrm{Pb}$ and $\mathrm{Lu}-\mathrm{Hf}$ data are available at http://www.geolsoc.org.uk/SUP0000

Zircon is a highly refractory and robust mineral, and the $\mathrm{U}-\mathrm{Pb}$ and $\mathrm{Lu}-\mathrm{Hf}$ isotope systems of detrital zircon in a sediment or sedimentary rock are excellent recorders of the crystallisation age and evolution of the (proto)source rock, i.e. the igneous or metamorphic rock in which the zircon originally formed (e.g. Hawkesworth \& Kemp 2006). These properties are thought to provide distinctive source terrane signatures (e.g. Williams 2001), and are therefore utilized in 
sedimentary provenance studies (e.g. Veevers et al. 2005, 2006; Augustsson et al. 2006; Veevers \& Saeed 2007), whose ultimate goal is to trace the detrital zircon population of sedimentary rocks (commonly sandstone) back to their (mainly granitoid) sources (e.g. Fedo et al. 2003). Some studies have, however, indicated that the direct link between detrital zircon age and Hf isotope and source terrane may be questionable — because of recycling of older sediments (e.g. Andersen et al. 2011; Kristoffersen et al. 2014), which facilitates mixing of detritus from different sources, and because the $\mathrm{U}-\mathrm{Pb}$ age and $\mathrm{Hf}$ isotope signature of various source terranes may not be sufficiently characteristic for them to be distinguishable (Andersen 2014)

With a long and well-preserved record of clastic sedimentary rocks ranging in age from Neoproterozoic to Recent, the older of which (Neoproterozoic to Triassic) formed in a Gondwana setting (Catuneanu et al. 2005; Shone \& Booth 2005; Gresse et al. 2006), South Africa provides an ideal testing ground for detrital zircon as a provenance indicator. The importance of factors such as sedimentary recycling and indistinct source characteristics can be evaluated by detailed studies of well-preserved deposits, of which stratigraphy, depositional environment and tectonic setting are well constrained. Based on detrital zircon $\mathrm{U}-\mathrm{Pb}$ and $\mathrm{Lu}-\mathrm{Hf}$ data from Permian Vryheid Formation sandstones of the main Karoo basin in eastern South Africa, Veevers and Saeed (2007) suggested that detritus was transported from primary sources in central Antarctica to depositional basins in present-day southern Africa and adjacent parts of the Gondwana supercontinent in late Palaeozoic time.

The sandstones and conglomerates of the Ordovician Natal Group (Thomas et al. 1992; Marshall 2006) predate the Karoo sediments studied by Veevers and Saeed (2007) by ca. 200 Ma. These rocks thus hold a potential key role for the understanding of the detrital zircon 
budget of Phanerozoic sedimentary sequences in SW Gondwana: If significant amounts of material from central Antarctica was transported to southern Africa in Permian time, detrital zircon in the older Natal Group should show age and Hf isotope characteristics significantly different from that of the Vryheid Formation sandstones. Furthermore, the depositional basin of the Natal Group was located close to possible sources in Antarctica and Mozambique, and it was deposited on a variety of basement rocks, including Archaean rocks of the Kaapvaal craton and various igneous and metamorphic rocks of the late Mesoproterozoic Natal Sector of the Namaqua-Natal Province. Contributions from local basement sources would therefore show distinctive detrital zircon signatures.

In the present study, we have analysed detritial zircon from selected sedimentary rocks of the Natal Group to provide an independent test of the provenance model of Veevers and Saeed (2007), and to evaluate alternative sources of detritus in southern Africa and adjacent parts of Gondwana. Since the Mesoproterozoic basement rocks of eastern South Africa are very poorly constrained by published Hf isotope data, it has been necessary also to perform a pilot study on granitoid plutons that make up a substantial and zircon-fertile component of the regional basement.

\section{Geological setting}

The geology of southern Africa is dominated by the Archaean Kaapvaal Craton which preserves a record of c. $1000 \mathrm{Ma}$ of geological history spanning from c. 3600 to c. 2700 (e.g. Hunter et al. 2006). It comprises largely granitoid rocks with a tonalite-trondhjemitegranodioritic composition (Hunter et al. 2006; Robb et al. 2006), infolded greenstone belts and their remnants, which include the well-studied Barberton Greenstone Belt (Brandl et al. 2006), and volcano-sedimentary cover sequences (Hunter et al. 2006) such as the Pongola 
Supergroup (e.g. Gold 2006), the Dominion Group (e.g. Marsh 2006), and the Witwatersrand (e.g. McCarthy 2006) and Ventersdorp Supergroups (e.g. van der Westhuizen et al. 2006). To the north the Kaapvaal Craton borders the Neoarchaean Limpopo Belt, which comprises mostly gneisses (Kramers et al. 2006). The granitoid rocks and greenstone belts of the Kaapvaal Craton, as well as some sedimentary rocks, and the Limpopo Belt are well covered by both U-Pb and Lu-Hf data (Zeh et al. 2007, 2008, 2009, 2010, 2011, 2012, 2013; Gerdes \& Zeh 2009), while for the volcano-sedimentary cover sequences Lu-Hf data are only available for the Eldorado Reef of the uppermost Witwatersrand Supergroup (Koglin et al. 2010). At its southern and western margin the Kaapvaal Craton is bounded by the Namaqua-Natal Province (e.g. Cornell et al. 2006).

The Namaqua-Natal Province is a Mesoproterozoic orogenic belt related to the amalgamation of the supercontinent Rodinia (e.g. Cornell et al. 2006). It forms a continuous belt from the Namaqua Sector in southern Namibia and NW South Africa (Northern Cape province) to the Natal Sector in eastern South Africa (KwaZulu-Natal province), with the between-lying area covered by the Carboniferous to Triassic Karoo Supergroup (Cornell et al. 2006). Its southern boundary is formed by the Neoproterozoic to early Cambrian Saldania Belt (e.g. Cornell et al. 2006). Sm-Nd work has shown that, while the Natal Sector has a juvenile nature (Eglington et al. 1989; Thomas \& Eglington 1990), the Namaqua Sector has a more prolonged crustal history (Yuhara et al. 2001; Pettersson et al. 2009). The juvenile nature of the Natal sector is also supported by Hf data (Spencer et al. 2015). The southern two-thirds of the Natal Sector are dominated by granitoid rocks which make up $>80 \%$ of the exposed area (Eglington et al. 2003). The Oribi Gorge Suite, which consists of 10 rapakivi-charnockite plutons emplaced in two episodes of intrusion at $\sim 1070$ and $\sim 1030 \mathrm{Ma}$, is the most extensive of these granitoids (Eglington et al. 2003). 
From the end of the Pan-African orogeny in late Neoproterozoic time southern Africa remained within a stable supercontinental setting, Gondwana, until its breakup in Jurassic time (e.g. Torsvik \& Cocks 2013). Neighbours during this time were South America, the Falkland Plateau, the Ellsworth-Whitmore Mountains and Dronning Maud Land (Torsvik \& Cocks 2013). In this setting continental cover sequences were deposited, ranging in depositional age from Neoproterozoic to Triassic. In the Early Ordovician Period (480 Ma) South Africa was located at $\sim 20^{\circ} \mathrm{S}$, and, as a result of southward drift, it was located at $\sim 35^{\circ}$ S (Torsvik \& Cocks 2013) by the Late Ordovician Period (445 Ma). Prior to this, in the Neoproterozoic to Cambrian Periods, the western part of South Africa was affected by the Saldanian orogeny, leading to granite emplacement (e.g. Scheepers \& Armstrong 2002; Chemale Jr. et al. 2010; Villaros et al. 2012), deposition of sedimentary rocks (e.g. Gresse et al. 2006) and the development of the Cape basin (Tankard et al. 2009). Deposition in the Cape basin lasted from the Ordovician to the Early Carboniferous Period (Tankard et al. 2009); the Ordovician Natal Group is contemporaneous with at least some of this (Cape Supergroup) succession (Shone \& Booth 2005; Tankard et al. 2009).

Well-preserved cover sequences cropping out in South Africa for which U-Pb (and some LuHf) data are available include the Neoproterozoic Cango Caves and Kansa Groups (Naidoo et al. 2013), the Neoproterozoic Nama Group (Blanco et al. 2011), Neoproterozoic sedimentary rocks from the Saldania Belt (Frimmel et al. 2013), the early Palaeozoic Cape Supergroup (Fourie et al. 2010; Vorster 2013), and the Carboniferous-Triassic Karoo Supergroup (Veevers \& Saeed 2007; Vorster 2013). Veevers \& Saeed (2007) argued for a distant (central Antarctic) source for late Mesoproterozoic and Neoproterozoic zircon in Permian sandstones from the main Karoo basin in eastern South Africa (province of KwaZulu-Natal). A distant provenance (Mozambique) has also been suggested for the Ordovician Natal Group based on 
palaeocurrent data indicating a source to the north and NE of the depositional basin (Thomas et al. 1992; Marshall 2002) and a c. $580 \mathrm{Ma} \mathrm{K}-\mathrm{Ar}$ age recorded for detrital muscovite (Thomas et al. 1992).

\section{The Natal Group}

The mainly maroon-coloured arkosic sandstones and quartz arenites, with interbedded mudrock and conglomerate units, of the Ordovician Natal Group were deposited on Archaean to Mesoproterozoic basement of the Kaapvaal Craton and the Natal Sector of the NamaquaNatal Province (Hobday \& von Brunn 1979; Marshall 2002). The geometry and tectonic setting of the Natal Group sedimentary basin is uncertain, having been referred to as a halfgraben foreland basin (Hobday \& von Brunn 1979), a foreland graben basin (Marshall 2002), a divergent margin basin (Shone \& Booth 2005), and a transpressional foreland basin (Tankard et al. 2009). The main outcrops of the Natal Group are found within the province of KwaZulu-Natal (South Africa), from Hlabisa (Fig. 1) in the north to just south of Hibberdene (Marshall 2006) in the south. The southern limit of the Natal Group basin has traditionally been defined by the Dweshula High (Fig. 1; e.g. Marshall 2002, 2006), smaller outcrops of the Natal Group occuring as much as $30 \mathrm{~km}$ south of this palaeo-topographic high are, however, also known (Marshall 2002; Hicks 2010). North of the Tugela Thrust Front (Fig. 1) the Natal Group rests on Archaean rocks of the Kaapvaal Craton, whereas to the south it rests nonconformably on the Namaquan (Mesoproterozoic) granitoids and gneisses of the Natal Sector (Marshall 2006). It is generally disconformably overlain by the Carboniferous-Permian Dwyka Group of the Karoo Supergroup (Marshall 2006), except for south of the Dweshula High (Fig. 1) where it is occasionally unconformably overlain by the Devonian Msikaba Formation (Hicks 2010). 
The Natal Group (Fig. 2) comprises the Durban Formation, which is subdivided into the Ulundi, Eshowe, Kranskloof, Situndu, Dassenhoek and Melmoth Members, and the Mariannhill Formation, which is subdivided into the Tulini, Newspaper and Westville Members (Marshall 2002, 2006). The Natal Group sediments are interpreted to have been deposited in at least two cycles of sedimentation, the first being initiated with the deposition of the conglomerates and interbedded sandstones of the Ulundi Member and closed by the initiation of the second cycle with deposition of the small-pebble conglomerates of the Tulini Member (Marshall 2006). A possible third cycle of sedimentation was initiated with the deposition of the Westville Member, the product of which might have been, to a large extent, removed by erosion prior to the deposition of the glaciogenic sediments of the Permian Dwyka Group (Karoo Supergroup) (Marshall 2006). Marshall (2006) interpreted these cycles to have been caused by uplift of the provenance area, which he thought to have been located in the Pan-African belt of southern Mozambique (Thomas et al. 1992; Marshall 2002, 2006), or by renewed subsidence of the depositional basin. While a mainly fluvial origin of the Natal Group (Hobday \& von Brunn 1979; Marshall \& von Brunn 1999; Marshall 2002, 2006) is generally accepted, the origin of the silicified quartz arenites of the Kranskloof and Dassenhoek Members is somewhat disputed (e.g. Liu \& Cooper 1998; Marshall 1999). These two members have been interpreted as fluvial and eolian reworking of the fluvial Eshowe Member (Marshall \& von Brunn 1999; Marshall 2002; 2006), and as shallow-marine, tidallyinfluenced sequences (Liu \& Cooper 1998).

\section{Material studied}

Eight sedimentary rock samples were analysed, comprising one quartzite clast and one matrix-dominated sample from the basal Ulundi Member conglomerate, and sandstone 
samples from the Ulundi, Eshowe, Dassenhoek, Tulini and Newspaper Members. These samples were chosen to provide a reasonable coverage of both geographic location and stratigraphic level. Sample localities are given in Figure 1, and their coordinates are listed in Table 1. $\mathrm{U}-\mathrm{Pb}$ data of the sedimentary rocks are given in Figure 3, and $\mathrm{Lu}-\mathrm{Hf}$ data are given in Figure 4 and 5.

In order to provide some Hf data for comparison with potential local bedrock sources, two granite samples - SA12/24 and SA13/133, belonging to the Mgeni and Fafa plutons, respectively, of the Oribi Gorge Suite within the Mzumbe Terrane of the Natal Sector - were dated (Fig. 6) and their Lu-Hf content was analysed (Fig. 4). This data, combined with the Hf data of Spencer et al. (2015) provides an extensive Hf signature of the zircon-fertile lithologies in the region.

\section{Analytical methods}

The samples were crushed, and their heavy mineral fractions were extracted by pan-washing, and, in the cases of SA12/06 and SA12/28, heavy liquid (sodium heteropolytungstate) separation. No magnetic separation was performed to avoid introducing an artificial bias (Sircombe \& Stern 2002; Andersen et al. 2011). Random selections of zircon grains were picked, cast in epoxy resin, polished and imaged by cathodoluminescence (CL) using a JEOL JSM 6460LV scanning electron microscope at the Department of Geosciences, University of Oslo.

$\mathrm{U}-\mathrm{Pb}$ and $\mathrm{Lu}-\mathrm{Hf}$ analyses were done by LA-ICPMS, using a Nu Plasma HR multi-collector mass spectrometer equipped with a NewWave LUV 213 Nd-YAG and a Cetac LSX-213 G2+ laser microprobe at the Department of Geosciences, University of Oslo. The analytical 
protocols of Andersen et al. (2009) and Rosa et al. (2009) were followed for U-Pb, whereas for Lu-Hf those of Elburg et al. (2013) were used. Ablation conditions for the NewWave LUV 213 laser microprobe were: beam diameter $40 \mu \mathrm{m}$ (aperture imaging mode), pulse frequency $10 \mathrm{~Hz}$ and beam fluence c. $0.06 \mathrm{~J} / \mathrm{cm}^{2}$ for $\mathrm{U}-\mathrm{Pb}$, and beam diameter $55-60 \mu \mathrm{m}$ (aperture imaging mode), pulse frequency $5 \mathrm{~Hz}$ and beam fluence c. $2 \mathrm{~J} / \mathrm{cm}^{2}$ for $\mathrm{Lu}-\mathrm{Hf}$; in both cases using static ablation. For the Cetac LSX-213 G2+ laser microprobe ablation conditions were: beam diameter $40 \mu \mathrm{m}$ (aperture imaging mode), pulse frequency $10 \mathrm{~Hz}$ and beam fluence $<0.78 \mathrm{~J} / \mathrm{cm}^{2}$ for $\mathrm{U}-\mathrm{Pb}$, and beam diameter $50 \mu \mathrm{m}$ (aperture imaging mode), pulse frequency $5 \mathrm{~Hz}$ and beam fluence c. $15 \mathrm{~J} / \mathrm{cm}^{2}$ for $\mathrm{Lu}-\mathrm{Hf}$; in both cases using static ablation. Data reduction was done using an interactive, in-house Microsoft Excel 2003 spreadsheet programme for $\mathrm{U}-\mathrm{Pb}$, and using $\mathrm{Nu}$ Instruments built-in software for $\mathrm{Lu}-\mathrm{Hf}$.

U-Pb ages were calculated using the decay constants of Steiger \& Jäger (1977). Discordance percentage were calculated as described in Kristoffersen et al. (2014). Ages are given as ${ }^{206} \mathrm{~Pb}-{ }^{238} \mathrm{U}$ ages if younger than or equal to $600 \mathrm{Ma}$, otherwise the ${ }^{207} \mathrm{~Pb}-{ }^{206} \mathrm{~Pb}$ ages are used. Only grains with less than $\pm 10 \%$ central discordance are included.

Zircons GJ-1 $\left({ }^{207} \mathrm{~Pb}-{ }^{206} \mathrm{~Pb}\right.$ age $=609 \pm 1 \mathrm{Ma}$; Jackson et al. 2004$), 91500\left({ }^{207} \mathrm{~Pb}-{ }^{206} \mathrm{~Pb}\right.$ age $=$ 1065 $\pm 1 \mathrm{Ma}$; Wiedenbeck et al. 1995) and A382 (concordia age = 1876 \pm 2 Ma; Huhma et al. 2012) were used as U-Pb standards. Repeated analyses of the in-house reference zircon $\mathrm{C}$ (ID-TIMS, weighted average ${ }^{207} \mathrm{~Pb}-{ }^{206} \mathrm{~Pb}$ age $=556.4 \pm 1.5 \mathrm{Ma}$; J. Lamminen, pers. comm. 2011) during the period the samples were analysed gave a weighted average ${ }^{207} \mathrm{~Pb}-{ }^{206} \mathrm{~Pb}$ age of $559 \pm 3 \mathrm{Ma}(2 \sigma, \mathrm{MSWD}=0.76$, probability of fit $=0.87, \mathrm{n}=44)$. During the period the samples were analysed, repeated analyses of the Mud Tank zircon $\left({ }^{176} \mathrm{Hf} /{ }^{177} \mathrm{Hf}=0.282507 \pm 6\right.$, solution analysis; Woodhead \& Hergt 2005) yielded ${ }^{176} \mathrm{Hf} /{ }^{177} \mathrm{Hf}=0.282509 \pm 30(2 \mathrm{SD} ; \mathrm{n}=139)$ 
and the in-house reference zircon LV-11 $\left({ }^{176} \mathrm{Hf} /{ }^{177} \mathrm{Hf}=0.282830 \pm 28\right.$, solution analysis; Heinonen et al. 2010$)$ yielded ${ }^{176} \mathrm{Hf} /{ }^{177} \mathrm{Hf}=0.282827 \pm 55(2 \mathrm{SD} ; \mathrm{n}=99)$, the latter $\left( \pm 2 \varepsilon_{\mathrm{Hf}}\right)$ is accepted as a conservative estimate of the precision of the method. A decay constant value for

${ }^{176} \mathrm{Lu}$ of $1.867 \times 10^{-11}$ year $^{-1}$ (Söderlund et al. 2004), and the present-day chondritic ${ }^{176} \mathrm{Hf} /{ }^{177} \mathrm{Hf}=0.282785$ and ${ }^{176} \mathrm{Lu} /{ }^{177} \mathrm{Hf}=0.0336$ (Bouvier et al. 2008) have been used in all $\varepsilon_{\mathrm{Hf}}$ calculations. We have adopted the depleted mantle parameters of Griffin et al. (2000); this model, modified to the decay constant and CHUR parameters used, gives present-day ${ }^{176} \mathrm{Hf} /{ }^{177} \mathrm{Hf}=0.28325\left(+16.4 \varepsilon_{\mathrm{Hf}}\right.$, similar to average mid-ocean ridge basalt $)$ from a chondritic initial ${ }^{176} \mathrm{Hf} /{ }^{177} \mathrm{Hf}$ at $4.56 \mathrm{Ga}$ and ${ }^{176} \mathrm{Lu} /{ }^{177} \mathrm{Hf}=0.0388$.

\section{Data handling}

Concordia plots and ages, and weighted average ages were calculated using Isoplot (Ludwig 2008). Histogram, kernel density estimate (KDE), empirical cumulative distribution function (ECDF) and $\varepsilon_{\mathrm{Hf}}$ plots were made using the R programming language and statistical computing environment (R Development Core Team 2015) with the ggplot2 plotting system (Wickham 2009). 1D KDE functions were calculated using the algorithm of Botev et al. (2010); 1D gaussian KDE functions with a fixed bandwidth=30 were also produced. 2D KDE functions were calculated using the R-function $k d e 2 d$ from the MASS package (Venables \& Ripley 2002), over an equally spaced 100x100 grid spanning from 400 to 4000 in the $\mathrm{x}$-direction and -15 to 15 in the $y$-direction using fixed bandwidths of 30 and 1.5 in the $x$ - and y-directions, respectively. 1D two sample Kolmogorov-Smirnoff (K-S) tests were calculated using the ks.test function in R. 2D two sample K-S tests were calculated using the MATLAB-function $k s t e s t \_2 s \_2 d$ (available from MATLAB Central). The two sample K-S test is a measure of the maximum vertical distance $\left(D_{\max }\right)$ between two ECDFs. A probability value $(p)$ is calculated 
for $D_{\max }$ to determine if $D_{\max }$ is the result of random sampling error or a true difference in the data. If $\mathrm{p}>\alpha$ ( $\alpha$ typically 0.05 in detrital zircon provenance studies) it is deemed unlikely that the samples are from different populations, the reverse is true for $p<\alpha$.

KDE curves represent probability densities as a function of zircon age, and the probability of finding a zircon within any age interval is given by the corresponding area under the curve,

i.e. integral of the KDE function $a(t)$ over the age interval of interest $\left(t_{\min }\right.$ to $\left.t_{\max }\right): \int_{t_{\min }}^{t_{\max }} a(t) d t$ in which $a(t)$ is the KDE function of interest normalized to unit area (i.e. $\left.\int_{-\infty}^{+\infty} a(t) d t=1\right)$. This integral must be solved numerically.

Satkoski et al. (2013) introduced a "likeness" parameter for pairs of detrital zircon age distributions defined by

$$
L=1-\frac{1}{2} \sum_{i=1}^{N}\left|a_{i}-b_{i}\right|
$$

where $a_{i}$ and $b_{i}$ are values of two KDE functions whose values are known at N points along the time axis. The summation term in equation (1) is a simple, stepwise numeric approximation to the integral of the difference between two KDE functions over the time interval of interest, i.e.:

$$
\sum_{i=1}^{N}\left|a_{i}-b_{i}\right| \approx \frac{1}{\Delta t} \int_{t_{\min }}^{t_{\max }} \mid a(t)-b(t) d t
$$

where $\Delta t$ is the distance between the adjacent, equally spaced points where the values of $a$ and $b$ in equation (1) were determined. 
Bivariate $\mathrm{U}-\mathrm{Pb}$ and $\mathrm{Lu}-\mathrm{Hf}$ data have mainly been visualized in simple scatter plots or by plots of model ages derived from the data (e.g. Veevers \& Saeed 2007), although contoured 3D probability density surfaces based on the KDE model have also been sporadically used (Andersen 2002, 2013). However, the likeness parameter of Satkoski et al. (2013) may easily be extended to bivariate data, summing over differences between pairs of values on 3D probability density surfaces over the age- $\varepsilon_{\mathrm{Hf}}$ plane taken at regularly spaced points in an M by $\mathrm{N}$ grid:

$$
L_{2}=1-\frac{1}{2} \sum_{j=1}^{M} \sum_{i=1}^{N}\left|a_{i, j}-b_{i, j}\right|
$$

in which both probability density functions must be normalized to unit volume, i.e.

$$
\int_{-\infty-\infty}^{+\infty} \int_{-\infty}^{+\infty} a\left(t, \varepsilon_{H f}\right) d t d \varepsilon_{H f}=1 .
$$

As the likeness parameter of Satkoski et al. (2013) is a much more robust measure of similarity/dissimilarity between pairs of detrital zircon samples (Satkoski et al. 2013) the results of the likeness tests are preferred over those of K-S tests.

\section{Results}

\section{Granites}

Zircons in the Mgeni pluton sample (SA12/24) are discordant (Fig. 6a), but the 10 least discordant grains $(-4 \%<$ discordance $<1 \%)$ give a weighted average ${ }^{207} \mathrm{~Pb}-{ }^{206} \mathrm{~Pb}$ age of $1061 \pm 8 \mathrm{Ma}\left(95 \%\right.$ confidence, MSWD=0.70); the sample has an $\varepsilon_{\mathrm{Hf}}$-value of $3.7 \pm 1.1(2 \sigma)$

(Fig. 4). The Fafa pluton sample (SA13/133) gives a concordia age (Fig. 6b) of 1086 \pm 6 Ma $(2 \sigma, \mathrm{MSWD}=0.00051)$ and has an $\varepsilon_{\mathrm{Hf}}$-value of $7.2 \pm 1.7(2 \sigma)($ Fig. 4$)$. The positive $\varepsilon_{\mathrm{Hf}}$-values 
for both of these intrusions agree with the generally juvenile nature of the Mesoproterozoic rocks in the Natal Sector of the Namaqua-Natal Province (Fig. 7) (e.g. Eglington et al. 1989; Thomas \& Eglington 1990; Spencer et al. 2015).

\section{Sedimentary rocks}

The two conglomerate samples from the basal Ulundi Member are dominated by Palaeo- to Mesoarchaean (3600-2940 Ma) detrital zircon (Fig. 3), whose $\varepsilon_{\mathrm{Hf}}$-values range from +3 to -4 (Fig. 5). In contrast, the six sandstone samples from the Ulundi, Eshowe, Dassenhoek, Tulini and Newspaper Members are all dominated by a late Mesoproterozoic to earliest Neoproterozoic (1150-950 Ma) age zircon (Fig. 3). An additional, smaller, Neoproterozoic (700-500 Ma) fraction of variable size is also found in all of the sandstone samples. The late Mesoproterozoic to earliest Neoproterozoic fraction has an overall $\varepsilon_{\mathrm{Hf}}$-range of +11 to -13 (Fig. 4), with 95\% (246/258) of the grains plotting above the CHUR (chondritic uniform reservoir) curve. The Neoproterozoic fraction has a more crustally influenced $\varepsilon_{\mathrm{Hf}}$-signature, where $98 \%(148 / 151)$ of the zircons have $\varepsilon_{\mathrm{Hf}}$ between +6 and -6 . Minor Archaean, Palaeoproterozoic and Mesoproterozoic fractions are also present in several of the sandstone samples. Pre-1400 Ma zircons are most abundant in the northern part of the outcrop area (samples SA12/39, SA12/27, SA12/42, SA12/43), while zircons of this age are almost absent from the southern samples (SA12/20, SA12/06).

\section{Discussion}

The detrital zircon age and Hf isotope distribution patterns in Figures 3 through 5 suggest that three main detrital zircon components are present in the rocks of the Natal Group. (1): Palaeoto Meosarchaean, (2) Mesoproterozoic to earliest Neoproterozoic, and (3) Neoproterozoic 
age, with characteristic $\varepsilon_{\mathrm{Hf}}$-ranges of +3 to $-8,+11$ to -13 and +10 to -11 , respectively. To understand the overall provenance characteristics of the Natal Group, the origin of each of these components needs to be identified, and the differences in relative abundance between samples should be characterized.

\section{Similarity and differences between samples}

The most obvious inter-sample difference observed is between the Ulundi conglomerate samples with a high proportion Archaean grains on one hand, and all of the sandstone samples dominated by Proterozoic zircon on the other (Figs. 3, 4, 5). To quantify these relationships, univariate (age) and bivariate (age $+\mathrm{Hf}$ isotope) likeness values have been calcuated.

Pairwise one-dimensional (Table 2) and two-dimensional likeness values (Table 3) show a high degree of similarity among the sandstone samples, close to the average likeness expected from samples drawn from a single population $(0.72 \pm 0.06$ for $\mathrm{n} \approx 100$; Satkoski et al. 2013). The likeness values between the two samples of Ulundi conglomerate (1D: 0.79, 2D: 0.81) suggest that the detrital zircon patterns of these samples are also indistinguishable. Likeness values comparing the conglomerate and sandstone samples (1D: <0.14, 2D: <0.13) confirm the significant difference between these groups suggested from visual inspection.

Compared to the results of the K-S tests (Table 4 and 5) and the ECDF plot (Figure 8) these results show that the absence of pre-1400 Ma zircon from the southern part of the outcrop area of the Natal Group may reflect the existence of Meso-Palaeoproterozoic sources to the north of the basin, which have not contributed in the south. On the other hand, if sedimentation in the north and south was not synchronous, sources of pre-1400 Ma zircon in 
the northern, earlier deposits could have been eroded away or blanketed over by the time the later, southern deposits were formed.

\section{Potential source areas}

The Archaean population of the two conglomerate samples (Fig 5) shows a clear similarity in its $\varepsilon_{\mathrm{Hf}}$-Values with values recorded in the Kaapvaal Craton (Zeh et al. 2009, 2011, 2013). Although the Limpopo Belt and the Zimbabwe Craton also have broadly similar signatures (Zeh et al. 2007, 2009, 2010; Gerdes \& Zeh 2009) and can therefore not be ruled out by zircon data, the Kaapvaal Craton is the Archaean domain in closest proximity to the depositional basin of the Natal Group and is, consequently, the most likely source area for the Archaean detrital zircons recorded in the basal Ulundi conglomerate samples. The quartzite clast from the Ulundi conglomerate (SA12/28) only contains Archaean zircons and could thus be derived from the quartzites of the Mesoarchaean Pongola Supergroup (e.g. Wronkiewicz \& Condie 1989; Gold 2006) on the Kaapvaal Craton. The Archaean detrital zircon component disappears up stratigraphy from the basal Ulundi conglomerate to the overlying sandstone. The reason could either be a change in input to the basin, or that Archaean source rocks of the Kaapvaal Craton were blanketed over by deposition of the first sediments of the Ulundi Member. In addition to its dominant Archaean population the Ulundi matrix sample (SA12/29) also contain three, near-concordant, middle Mesoproterozoic to earliest Neoproterozoic zircon grains which could be derived from the Natal Sector of the NamaquaNatal Province where similar ages are recorded (e.g. Eglington 2006). This suggests that the source area shedding sediments to the Ulundi conglomerate was altogether proximal to the depositional basin. 
The Archaean grains recorded in the sandstone samples have similar $\varepsilon_{\mathrm{Hf}}-$ values as those of the conglomerate samples (Fig. 4-5), varying from slightly subchondritic to slightly superchondritic. One exception is the small cluster of c. 2730-2710 Ma zircons with an $\varepsilon_{\mathrm{Hf}^{-}}$ range of -7 to -8 (Fig. 4), which could point to protosource-rocks whose protoliths had an extended crustal history, such as seen in the Ancient Gneiss Complex of Swaziland (Zeh et al. 2011).

The largest age group recorded in this study, dominating all sandstone samples, is found at c. 1150-950 Ma and shows a consistent peak at c. 1030 Ma (Fig. 3). This time period corresponds with the Rodinia-related Namaquan Orogeny (e.g. Cornell et al. 2006). Rocks of this age are now exposed in the Natal and Namaqua Sectors of the Namaqua-Natal Province which stretches from the KwaZulu-Natal area in South Africa to southern Nambia. Sm-Nd data indicate that the (western) Namaqua Sector generally has a longer crustal history of the two domains (e.g. Yuhara et al. 2001; Pettersson et al. 2009); the only published $\varepsilon_{\mathrm{Hf}}$-values from the (western) Namaqua Sector (Cornell et al. 2013) are consistent with these observations. The (eastern) Natal Sector has a much more juvenile signature (e.g. Eglington $e t$ al. 1989; Thomas \& Eglington 1990). The superchondritic $\varepsilon_{\mathrm{Hf}}$-signatures of the granites reported in this study, also found in the data of Spencer et al. (2015), add supporting evidence to the juvenile nature of the Natal Sector. The Namaqua Sector is therefore an unlikely source area for the generally juvenile, late Mesoproterozoic to earliest Neoproterozoic zircons found in the Natal Group (Fig. 4); granitoid rocks of the Natal Sector (e.g. McCourt et al. 2006) are however, possible sources. Similar ages are, for instance, prevalent in the intrusive rocks of the Oribi Gorge Suite (Eglington et al. 2003; this study). Juvenile rocks of this age are also found in the Mozambique belt in southern (Grantham et al. 2003) and northeastern (Bingen et al. 2007) Mozambique, in the Ellsworth-Whitmore Mountains, Antarctica (Flowerdew et al. 
2007), in Dronning Maud Land, Antarctica (Bauer et al. 2003; Ramo et al. 2009) and on the Falkland Islands (Jacobs et al. 1999; Thomas et al. 2000). These areas were all adjacent to the depositional basin of the Natal Group (e.g. Torsvik \& Cocks 2013) at its presumed depositional age of $490 \mathrm{Ma}$ (Thomas et al. 1992).

Although the slightly smaller zircon population at c. 700-500 Ma (Fig. 3) is fairly consistent throughout the sandstone samples, there seems to be a tendency of increasing relative fractions of younger grains from north to south (Fig. 3). The bulk of the late Neoproterozoic to early Cambrian zircons have $\varepsilon_{\mathrm{Hf}}$-values indicative of a derivation from juvenile, Mesoproterozoic material reworked during the Pan-African Orogeny, while the youngest grains recorded $(<550 \mathrm{Ma}$ ) could point to a source in the Cape Granite Suite, towards the SW within present-day South Africa (Villaros et al. 2012).

\section{Implications}

Veevers \& Saeed (2007) observed detrital zircon patterns closely similar to those reported in this study in Permian sedimentary rocks in the main Karoo Basin of South Africa (Vryheid Formation) and in Dronning Maud Land, Antarctica. Their interpretation was that these sediments were derived from a common source in central Antarctica, which shed detritus to surrounding parts of Gondwana in the late Palaeozoic. And they inferred from Cambrian (meta)sediments with similar zircon signatures from the Welch Mountains, Antarctica and the Ellsworth-Whitmore Mountains that the same central Antarctica source was also active in the Cambrian period. However, apart from the Karoo, Dronning Maud Land, Welch Mountains, and the Ellsworth-Whitmore Mountains, similar detrital zircon signatures have been reported from sedimentary rocks in many parts of former Gondwana and over a range of depositional ages from Neoproterozoic to Permian, including southern Africa (Fourie et al. 2010; Blanco 
et al. 2011; Frimmel et al. 2013; Naidoo et al. 2013), Antarctica (Flowerdew et al. 2007; Vorster 2013), South America (Blanco 2010; Uriz et al. 2010; Ramos et al. 2014) and Australia (Veevers et al. 2006; Veevers \& Saeed 2007). Several of these sedimentary sequences show a high degree of Satkoski-likeness to the Natal Group sandstones and amongst each other (Table 6 and 7). Detrital zircon with similar age and Hf isotopic characteristics must therefore have been present over large surface areas in Gondwana much earlier than the Permian. This suggests either (1): that there has been a source feeding this vast area at least from Neoproterozoic to Permian time, (2): that these deposits are the result of recycling of older sedimentary sequences (the signatures thereby being a manifestation of the inherent resilience of zircon to physical and chemical weathering) or (3): that the various areas of Gondwana that fed these sandstone sequences are not sufficiently distinctive for them to be distinguished from age and $\mathrm{Hf}$ isotope data. If the first alternative is true, a source, possibly the central Antarctica source of Veevers \& Saeed (2007), must have fed sediments to Gondwana, at least semi-continuously, from its inception almost until its subsequent breakup. This would require an enormous amount of available material. As juvenile Mesoproterozoic rocks and juvenile Mesoproterozoic rocks reworked during Neoproterozoic time are a common Pan-Gondwanan feature (Fig. 9) (e.g. Beckinsale et al. 1977; Wareham et al. 2001; Jacobs et al. 2003; Viola et al. 2006; Ramo et al. 2009) the third, Pan-Gondwanan alternative is seen as the most likely, with a possible minor influence of the second, recycling alternative in, at least, some of these sequences.

Combined with the results of sedimentary sequences with similar detrital zircon patterns our results show that sedimentary sequences dominated by juvenile Mesoproterozoic zircon and Neoproterozoic zircon derived from juvenile, Mesoproterozoic material reworked during the 
Pan-African Orogeny are a common feature of neighbouring areas of former southern Gondwana. Thus the Permian Karoo and Dronning Maud Land sandstones of Veevers \& Saeed (2007) need not be derived from Cental Antarctica — similar signatures were abundant in adjacent areas from at least the Neoproterozoic — but could be the result of recycling, or could be derived from one of several (equally) likely source terranes.

\section{Conclusion}

Taken together these results (Fig. 3-5, 8; Table 2-5) show that the basal Ulundi conglomerates of the Natal Group are derived from the same proximal source, i.e. from late Archaean rocks of the Kaapvaal craton - possibly from the Pongola Supergroup. On the other hand, the stratigraphically higher sandstones in the sequence show uniform provenance characteristics, reflecting source areas with a typical Gondwanan signature comprising juvenile Mesoproterozoic material, and Neoproterozoic material derived from juvenile Mesoproterozoic protoliths reworked during the Pan-African Orogeny (Ireland et al. 1998; Goodge et al. 2002; Flowerdew et al. 2007; Veevers \& Saeed 2007; Fourie et al. 2010; Blanco et al. 2011; Villaros et al. 2012; Naidoo et al. 2013). Rocks with such age and Hf isotope characteristics are widespread across Gondwana, and thus the detrital zircons cannot be assigned to a specific source terrane, be it in central Antarctica or elsewhere.

The results should be taken as a reminder of the difficulty of ascertaining a provenance for detrital zircon, caused by sedimentary recycling or source terrane non-uniqueness: special care must be taken when using detrital zircon as evidence for far reaching conclusions, such as basin evolution and palaeogeography. 
Thanks to Siri Simonsen and Berit Løken Berg for assistance with the ICPMS and SEM, respectively. This is publication no. 49 from the Isotope Geology Laboratory at the Department of Geosciences, University of Oslo.

\section{References}

ANDERSEN, T. 2002. Correction of common lead in $\mathrm{U}-\mathrm{Pb}$ analyses that do not report ${ }^{204} \mathrm{~Pb}$. Chemical Geology, 192, 59-79, http://doi.org/10.1016/S0009-2541(02)00195-X.

ANDERSEN, T. 2013. Age, Hf isotope and trace element signatures of detrital zircons in the Mesoproterozoic Eriksfjord sandstone, southern Greenland: are detrital zircons reliable guides to sedimentary provenance and timing of deposition? Geological Magazine, 150, 426-440, http://doi.org/10.1017/S0016756812000623.

ANDERSEN, T. 2014. The detrital zircon record: Supercontinents, parallel evolution - or coincidence? Precambrian Research, 244, 279-287, http://doi.org/10.1016/j.precamres.2013.10.013.

Andersen, T., Andersson, U. B., Graham, S., Åberg, G. \& Simonsen, S. L. 2009. Granitic magmatism by melting of juvenile continental crust: new constraints on the source of Palaeoproterozoic granitoids in Fennoscandia from Hf isotopes in zircon. Journal of the Geological Society, London, 166, 233-247, http://doi.org/10.1144/0016-76492007-166.

Andersen, T., Saeed, A., Gabrielsen, R. H. \& Olaussen, S. 2011. Provenance characteristics of the Brumunddal sandstone in the Oslo Rift derived from $\mathrm{U}-\mathrm{Pb}, \mathrm{Lu}-\mathrm{Hf}$ and trace element analyses of detrital zircons by laser ablation ICMPS. Norwegian Journal of Geology, 91, 1-18. 
Augustsson, C., Münker, C., Bahlburg, H. \& Fanning, C. M. 2006. Provenance of late Palaeozoic metasediments of the SW South American Gondwana margin: a combined $\mathrm{U}-\mathrm{Pb}$ and Hf-isotope study of single detrital zircons. Journal of the Geological Society, London, 163, 983-995, http://doi.org/10.1144/0016-76492005-149.

Bauer, W., Thomas, R. J. \& Jacobs, J. 2003. Proterozoic-Cambrian history of Dronning Maud Land in the context of Gondwana assembly. In: Yoshida, M., Windley, B. F. \& Dasgupta, S. (eds) Proterozoic East Gondwana: Supercontinent Assembly and Breakup. Geological Society, London, Special Publications, 247-269, http://doi.org/10.1144/GSL.SP.2003.206.01.13.

Beckinsale, R. D., TARney, J., Darbyshire, D. P. F. \& HumM, M. J. 1977. Re-Sr and K-Ar age determinations on samples of the Falkland plateau basement at site 330, DSDP. Initial Reports of the Deep Sea Drilling Project, 36, 923-927.

Bingen, B., Viola, G., ET AL. 2007. Crustal architecture of the Mozambique belt in northeastern Mozambique: Perspective from U-Pb geochronology and Lu-Hf isotopes in zircon. In: 7. International Symposium on Applied Isotope Geochemistry, Abstract.

Blanco, G. 2010. Provenance of the Ediacaran-Early Palaeozoic Arroyo Del Soldado Group (Uruguay) and the Nama Group (Namibia): Geodynamic Implications for the SW- Gondwana amalgamation. 9-25.

Blanco, G., Germs, G. J. B., Rajesh, H. M., Chemale Jr., F., Dussin, I. A. \& Justino, D. 2011. Provenance and paleogeography of the Nama Group (Ediacaran to early Palaeozoic, 
Namibia): Petrography, geochemistry and $\mathrm{U}-\mathrm{Pb}$ detrital zircon geochronology. Precambrian Research, 187, 15-32, http://doi.org/10.1016/j.precamres.2011.02.002.

Botev, Z. I., Grotowski, J. F. \& Kroese, D. P. 2010. Kernel density estimation via diffusion. The Annals of Statistics, 38, 2916-2957, http://doi.org/10.1214/10-AOS799.

Bouvier, A., Vervoort, J. D. \& Patchett, P. J. 2008. The Lu-Hf and Sm-Nd isotopic composition of CHUR: Constraints from unequilibrated chondrites and implications for the bulk composition of terrestrial planets. Earth and Planetary Science Letters, 273, 48-57, http://doi.org/10.1016/j.epsl.2008.06.010.

Brandl, G., Cloete, M. \& Anhaeusser, C. R. 2006. Archean Greenstone Belts. In: Johnson, M. R., Anhaeusser, C. R. \& Thomas, R. J. (eds) Geology of South Africa. Geological Society of South Africa, 9-56.

Catuneanu, O., Wopfner, H., Eriksson, P. G., Cairncross, B., Rubidge, B. S., Smith, R. M. H. \& HANCOX, P. J. 2005. The Karoo basins of south-central Africa. Journal of African Earth Sciences, 43, 211-253, http://doi.org/10.1016/j.jafrearsci.2005.07.007.

Chemale JR., F., Scheepers, R., Gresse, P. G. \& Van Schmus, W. R. 2010. Geochronology and sources of late Neoproterozoic to Cambrian granites of the Saldania Belt. International Journal of Earth Sciences, 100, 431-444, http://doi.org/10.1007/s00531-010-0579-1.

Cornell, D. H., Thomas, R. J., Moen, H. F. G., Reid, D. L., Moore, J. M. \& Gibson, R. L. 2006. The Namaqua-Natal Province. In: Johnson, M. R., Anhaeusser, C. R. \& Thomas, R. J. (eds) The Geology of South Africa. Geological Society of South Africa, 325-379. 
Cornell, D. H., Brander, L., ZaCK, T. \& Kristoffersen, M. 2013. The Plat Sjambok Anorthosite and its tonalitic country rocks: Mesoproterozoic pre-tectonic intrusions in the Kaaien Terrane, Namaqua-Natal Province, southern Africa. International Geology Review, 55, 1471-1489, http://doi.org/10.1080/00206814.2013.780703.

Eglington, B. M. 2004. DateView: a windows geochronology database. Computers \& Geosciences, 30, 847-858, http://doi.org/10.1016/j.cageo.2004.06.002.

EgLington, B. M. 2006. Evolution of the Namaqua-Natal Belt, southern Africa - A geochronological and isotope geochemical review. Journal of African Earth Sciences, 46, 93111, http://doi.org/10.1016/j.jafrearsci.2006.01.014.

Eglington, B. M., HARMer, R. E. \& KerR, A. 1989. Isotope and Geochemical Constraints on Proterozoic Crustal Evolution in South-Eastern Africa. Precambrian Research, 45, 159174, http://doi.org/10.1016/0301-9268(89)90037-5.

Eglington, B. M., Thomas, R. J., Armstrong, R. A. \& Walraven, F. 2003. Zircon geochronology of the Oribi Gorge Suite, KwaZulu-Natal, South Africa: constraints on the timing of trans-current shearing in the Namaqua-Natal Belt. Precambrian Research, 123, 2946, http://doi.org/10.1016/S0301-9268(03)00016-0.

Elburg, M. A., Andersen, T., Bons, P. D., Simonsen, S. L. \& Weisheit, A. 2013. New constraints on Phanerozoic magmatic and hydrothermal events in the Mt Painter Province, South Australia. Gondwana Research, 24, 700-712, http://doi.org/10.1016/j.gr.2012.12.017. 
Fedo, C. M., Sircombe, K. N. \& RainbiRd, R. H. 2003. Detrital zircon analysis of the sedimentary record. In: Hanchar, J. M. \& Hoskin, P. W. O. (eds) Zircon. Reviews in Mineralogy \& Geochemistry 53, Mineralogical Society of America, 277-303.

Flowerdew, M. J., Millar, I. L., Curtis, M. L., Vaughan, A. P. M., Horstwood, M. S. A., Whitehouse, M. J. \& FAnning, C. M. 2007. Combined U-Pb geochronology and Hf isotope geochemistry of detrital zircons from early Paleozoic sedimentary rocks, EllsworthWhitmore Mountains block, Antarctica. Geological Society of America Bulletin, 119, 275288, http://doi.org/10.1130/B25891.1.

Fourie, P. H., ZimMERMANN, U., ET AL. 2010. Provenance and reconnaissance study of detrital zircons of the Palaeozoic Cape Supergroup in South Africa: revealing the interaction of the Kalahari and Río de la Plata cratons. International Journal of Earth Sciences, 100, 527-541, http://doi.org/10.1007/s00531-010-0619-x.

Frimmel, H. E., Basei, M. A. S., Correa, V. X. \& Mbangula, N. 2013. A new lithostratigraphic subdivision and geodynamic model for the Pan-African western Saldania Belt, South Africa. Precambrian Research, 231, 218-235, http://doi.org/10.1016/j.precamres.2013.03.014.

GERDES, A. \& ZEH, A. 2009. Zircon formation versus zircon alteration - New insights from combined U-Pb and Lu-Hf in-situ LA-ICP-MS analyses, and consequences for the interpretation of Archean zircon from the Central Zone of the Limpopo Belt. Chemical Geology, 261, 230-243, http://doi.org/10.1016/j.chemgeo.2008.03.005. 
GoLD, D. J. C. 2006. The Pongola Supergroup. In: Johnson, M. R., Anhaeusser, C. R. \& Thomas, R. J. (eds) The Geology of South Africa. Geological Society of South Africa, 135147.

Goodge, J. W., Myrow, P., Williams, I. S. \& Bowring, S. A. 2002. Age and Provenance of the Beardmore Group, Antarctica: Constraints on Rodinia Supercontinent Breakup. The Journal of Geology, 110, 393-406, http://doi.org/10.1086/340629.

Grantham, G. H., Maboko, M. \& Eglington, B. M. 2003. A review of the evolution of the Mozambique Belt and implications for the amalgamation and dispersal of Rodinia and Gondwana. In: Yoshida, M., Windley, B. F. \& Dasgupta, S. (eds) Proterozoic East Gondwana: Supercontinent Assembly and Breakup. Geological Society, London, Special Publications, 401-425, http://doi.org/10.1144/GSL.SP.2003.206.01.19.

Gresse, P. G., VON VEH, M. W. \& FrIMMEL, H. E. 2006. Namibian (Neoproterozoic) to early Cambrian successions. In: Johnson, M. R., Anhaeusser, C. R. \& Thomas, R. J. (eds) The Geology of South Africa. Geological Society of South Africa, 395-420.

Griffin, W. L., Pearson, N. J., Belousova, E., Jackson, S. E., van Achterbergh, E., O'REILLY, S. Y. \& SHEE, S. R. 2000. The Hf isotope composition of cratonic mantle: LAMMC-ICPMS analysis of zircon megacrysts in kimberlites. Geochimica et Cosmochimica Acta, 64, 133-147, http://doi.org/10.1016/S0016-7037(99)00343-9.

HAWKESWORTH, C. J. \& KEMP, A. I. S. 2006. Using hafnium and oxygen isotopes in zircons to unravel the record of crustal evolution. Chemical Geology, 226, 144-162, http://doi.org/10.1016/j.chemgeo.2005.09.018. 
HeInONEn, A. P., ANDERSEn, T. \& RÄMÖ, O. T. 2010. Re-evaluation of Rapakivi petrogenesis: Source constraints from the Hf isotope composition of zircon in the Rapakivi Granites and associated mafic rocks of Southern Finland. Journal Of Petrology, 51, 16871709, http://doi.org/10.1093/petrology/egq035.

HICKS, N. 2010. Extended distribution of Natal Group within southern Kwazulu-Natal, South Africa: Implications for sediment sources and basin structure. South African Journal of Geology, 113, 287-306, http://doi.org/10.2113/gssajg.113.3.287.

HobDAY, D. K. \& VON BRUNN, V. 1979. Fluvial sedimentation and paleogeography of an early Paleozoic failed rift, southeastern margin of Africa. Palaeogeography, Palaeoclimatology, Palaeoecology, 28, 169-184, http://doi.org/10.1016/00310182(79)90117-2.

HuHMA, H., MÄNTTÄRRI, I., ET AL. 2012. The age of the Archaean greenstone belts in Finland. In: Hölttä, P. (ed.) The Archaean of the Karelia Province in Finland. Geological Survey of Finland, Special Paper, 74-175.

Hunter, D. R., Johnson, M. R., Anhaeusser, C. R. \& Thomas, R. J. 2006. Introduction. In: Johnson, M. R., Anhaeusser, C. R. \& Thomas, R. J. (eds) Geology of South Africa. Geological Society of South Africa, 1-8.

Ireland, T. R., Flöttmann, T., Fanning, C. M., Gibson, G. M. \& Preiss, W. V. 1998. Development of the early Paleozoic Pacific margin of Gondwana from detrital-zircon ages across the Delamerian orogen. Geology, 26, 243-246, http://doi.org/10.1130/00917613(1998)026<0243. 
Jackson, S. E., Pearson, N. J., Griffin, W. L. \& Belousova, E. A. 2004. The application of laser ablation-inductively coupled plasma-mass spectrometry to in situ $\mathrm{U}-\mathrm{Pb}$ zircon geochronology. Chemical Geology, 211, 47-69, http://doi.org/10.1016/j.chemgeo.2004.06.017.

Jacobs, J., Thomas, R. J., Armstrong, R. A. \& Henjes-Kunst, F. 1999. Age and thermal evolution of the Mesoproterozoic Cape Meredith Complex, West Falkland. Journal of the Geological Society, London, 156, 917-928, http://doi.org/10.1144/gsjgs.156.5.0917.

JACOBS, J., BAUER, W. \& FAnNING, C. M. 2003. Late Neoproterozoic/Early Palaeozoic events in central Dronning Maud Land and significance for the southern extension of the East African Orogen into East Antarctica. Precambrian Research, 126, 27-53, http://doi.org/10.1016/S0301-9268(03)00125-6.

JACOBSEN, S. B. \& WASSERbURG, G. J. 1980. Sm-Nd isotopic evolution of chondrites. Earth and Planetary Science Letters, 50, 139-155, http://doi.org/10.1016/0012-821X(80)90125-9.

Koglin, N., Zeh, A., Frimmel, H. E. \& Gerdes, A. 2010. New constraints on the auriferous Witwatersrand sediment provenance from combined detrital zircon $\mathrm{U}-\mathrm{Pb}$ and $\mathrm{Lu}-\mathrm{Hf}$ isotope data for the Eldorado Reef (Central Rand Group, South Africa). Precambrian Research, 183, 817-824, http://doi.org/10.1016/j.precamres.2010.09.009.

Kramers, J. D., McCourt, S. \& VAn ReEnen, D. D. 2006. The Limpopo Belt. In: Johnson, M. R., Anhaeusser, C. R. \& Thomas, R. J. (eds) Geology of South Africa. Geological Society of South Africa, 209-236. 
Kristoffersen, M., Andersen, T. \& Andresen, A. 2014. U-Pb age and Lu-Hf signatures of detrital zircon from Palaeozoic sandstones in the Oslo Rift, Norway. Geological Magazine, 151, 816-829, http://doi.org/10.1017/S0016756813000885.

LIU, K. W. \& COOPER, M. R. 1998. Tidalites in the Natal Group. South African Journal of Geology, 101, 307-312.

LUDWIG, K. R. 2008. User's Manual for Isoplot 3.70. Berkley Geochronology Center Special Publication No. 4.

LUGMAIR, G. W. \& MARTI, K. 1978. Lunar initial 143Nd/144Nd: Differential evolution of the lunar crust and mantle. Earth and Planetary Science Letters, 39, 349-357, http://doi.org/10.1016/0012-821X(78)90021-3.

MARSh, J. S. 2006. The Dominion Group. In: Johnson, M. R., Anhaeusser, C. R. \& Thomas, R. J. (eds) Geology of South Africa. Geological Society of South Africa, 149-154.

Marshall, C. G. A. 1999. Tidalites in the Natal Group: Discussion (S. Afr. J. Geol, 101, 307-312). South African Journal of Geology, 102, 405-409.

Marshall, C. G. A. 2002. The Stratigraphy, Sedimentology and Basin Evolution of the Natal Group. Council for Geosciences Memoir 91.

Marshall, C. G. A. 2006. The Natal Group. In: Johnson, M. R., Anhaeusser, C. R. \& Thomas, R. J. (eds) The Geology of South Africa. Geological Society of South Africa, 433441. 
Marshall, C. G. A. \& vON BrunN, V. 1999. The stratigraphy and origin of the Natal Group. South African Journal of Geology, 102, 15-25.

MCCARThy, T. S. 2006. The Witwatersrand Supergroup. In: Johnson, M. R., Anhaeusser, C. R. \& Thomas, R. J. (eds) Geology of South Africa. Geological Society of South Africa, 155186.

McCourt, S., Armstrong, R. A., Grantham, G. H. \& Thomas, R. J. 2006. Geology and evolution of the Natal belt, South Africa. Journal of African Earth Sciences, 46, 71-92, http://doi.org/10.1016/j.jafrearsci.2006.01.013.

Naidoo, T., Zimmermann, U. \& Chemale JR, F. 2013. The evolution of Gondwana: U-Pb, $\mathrm{Sm}-\mathrm{Nd}, \mathrm{Pb}-\mathrm{Pb}$ and geochemical data from Neoproterozoic to Early Palaeozoic successions of the Kango Inlier (Saldania Belt, South Africa). Sedimentary Geology, 294, 164-178, http://doi.org/10.1016/j.sedgeo.2013.05.014.

Pettersson, Å., Cornell, D. H., Yuhara, M. \& Hirahara, Y. 2009. Sm-Nd data for granitoids across the Namaqua sector of the Namaqua-Natal Province, South Africa. In: Reddy, S. M., Mazumder, R., Evans, D. A. D. \& Collins, A. S. (eds) Palaeoproterozoic Supercontinents and Global Evolution. Geological Society, London, Special Publications, 219-230, http://doi.org/10.1144/SP323.10.

R DEVElopment CoRE TEAM. 2015. R: A Language and Environment for Statistical Computing. http://www.r-project.org.

Ramo, O. T., Kurhila, M., Luttinen, A. V. \& Andersen, T. 2009. U-Pb-Nd-Hf isotope geochemistry of the Mesoproterozoic A-type granites in Mannefallknausane, western 
Dronning Maud Land, Antarctica. In: American Geophysical Union, Fall Meeting 2009, Abstract. \#V51C - 1687.

Ramos, V. A., Chemale, F., Naipauer, M. \& Pazos, P. J. 2014. A provenance study of the Paleozoic Ventania System (Argentina): Transient complex sources from Western and Eastern Gondwana. Gondwana Research, 26, 719-740, http://doi.org/10.1016/j.gr.2013.07.008.

Robb, L. J., Brandl, G., Anhaeusser, C. R. \& Poujol, M. 2006. Archean Granitoid Intrusions. In: Johnson, M. R., Anhaeusser, C. R. \& Thomas, R. J. (eds) The Geology of South Africa. Geological Society of South Africa, 57-94.

RosA, D. R. N., Finch, A. A., Andersen, T. \& InVERno, C. M. C. 2009. U-Pb geochronology and Hf isotope ratios of magmatic zircons from the Iberian Pyrite Belt. Mineralogy and Petrology, 95, 47-69, http://doi.org/10.1007/s00710-008-0022-5.

Satkoski, A. M., Wilkinson, B. H., HietPas, J. \& SAmson, S. D. 2013. Likeness among detrital zircon populations - An approach to the comparison of age frequency data in time and space. GSA Bulletin, 125, 1783-1799, http://doi.org/10.1130/B30888.1.

ScheEPERS, R. \& ARMSTRONG, R. 2002. New U-Pb SHRIMP zircon ages of the Cape Granite Suite: implications for the magmatic evolution of the Saldania Belt. South African Journal of Geology, 105, 241-256, http://doi.org/10.2113/105.2.163.

Shone, R. W. \& Booth, P. W. K. 2005. The Cape Basin, South Africa: A review. Journal of African Earth Sciences, 43, 196-210, http://doi.org/10.1016/j.jafrearsci.2005.07.013. 
SiRCOMBE, K. N. \& SteRn, R. A. 2002. An investigation of artificial biasing in detrital zircon $\mathrm{U}-\mathrm{Pb}$ geochronology due to magnetic separation in sample preparation. Geochimica et Cosmochimica Acta, 66, 2379-2397, http://doi.org/10.1016/S0016-7037(02)00839-6.

Söderlund, U., PAtchett, P. J., Vervoort, J. D. \& Isachsen, C. E. 2004. The ${ }^{176}$ Lu decay constant determined by $\mathrm{Lu}-\mathrm{Hf}$ and $\mathrm{U}-\mathrm{Pb}$ isotope systematics of Precambrian mafic intrusions. Earth and Planetary Science Letters, 219, 311-324, http://doi.org/10.1016/S0012$821 \mathrm{X}(04) 00012-3$.

Spencer, C. J., Thomas, R. J., Roberts, N. M. W., Cawood, P. A., Millar, I. \& Tapster, S. 2015. Crustal growth during island arc accretion and transcurrent deformation, Natal Metamorphic Province, South Africa: New isotopic constraints. Precambrian Research, 265, 203-217, http://doi.org/10.1016/j.precamres.2015.05.011.

STEIGER, R. H. \& JÄGER, E. 1977. Subcommission on geochronology: Convention on the use of decay constants in geo- and cosmochronology. Earth And Planetary Science Letters, 36, $359-362$.

Tankard, A., Welsink, H., Aukes, P., Newton, R. \& Stettler, E. 2009. Tectonic evolution of the Cape and Karoo basins of South Africa. Marine and Petroleum Geology, 26, 1379-1412, http://doi.org/10.1016/j.marpetgeo.2009.01.022.

Thomas, R. J. \& Eglington, B. M. 1990. A Rb-Sr, Sm-Nd and U-Pb zircon isotopic study of the Mzumbe Suite, the oldest intrusive granitoid in southern Natal, South Africa. South African Journal of Geology, 93, 761-765. 
Thomas, R. J., Marshall, C. G. A., Watkeys, M. K., Fitch, F. J. \& Miller, J. A. 1992. KAr and 40Ar/39Ar dating of the Natal Group, Southeast Africa: a post Pan-African molasse? Journal of African Earth Sciences, 15, 453-471, http://doi.org/10.1016/0899-5362(92)90028B.

Thomas, R. J., Eglington, B. M., Bowring, S. A., Retief, E. A. \& Walraven, F. 1993. New isotope data from a Neoproterozoic porphyritic granitoid- charnockite suite from Natal, South Africa. Precambrian Research, 62, 83-101, http://doi.org/10.1016/03019268(93)90095-J.

Thomas, R. J., Jacobs, J. \& Eglington, B. M. 2000. Geochemistry and isotopic evolution of the Mesoproterozoic Cape Meredith Complex, West Falkland. Geological Magazine, 137, 537-553, http://doi.org/10.1017/S0016756800004519.

Thomas, R. J., Jacobs, J., Horstwood, M. S. A., Ueda, K., Bingen, B. \& Matola, R. 2010. The Mecubúri and Alto Benfica Groups, NE Mozambique: Aids to unravelling ca. 1 and 0.5Ga events in the East African Orogen. Precambrian Research, 178, 72-90, http://doi.org/10.1016/j.precamres.2010.01.010.

TORSVIK, T. H. \& CocKS, L. R. M. 2013. Gondwana from top to base in space and time. Gondwana Research, 24, 999-1030, http://doi.org/10.1016/j.gr.2013.06.012.

Uriz, N. J., Cingolani, C. A., Chemale, F., Macambira, M. B. \& Armstrong, R. 2010. Isotopic studies on detrital zircons of Silurian-Devonian siliciclastic sequences from Argentinean North Patagonia and Sierra de la Ventana regions: comparative provenance. 
International Journal of Earth Sciences, 100, 571-589, http://doi.org/10.1007/s00531-0100597-z.

VAn Der Westhuizen, W. A., De Bruiyn, H. \& Meintjes, P. G. 2006. The Ventersdorp Supergroup. In: Johnson, M. R., Anhaeusser, C. R. \& Thomas, R. J. (eds) Geology of South Africa. Geological Society of South Africa, 187-208.

Veevers, J. J. \& SAeED, A. 2007. Central Antarctic provenance of Permian sandstones in Dronning Maud Land and the Karoo Basin: Integration of $\mathrm{U}-\mathrm{Pb}$ and TDM ages and host-rock affinity from detrital zircons. Sedimentary Geology, 202, 653-676, http://doi.org/10.1016/j.sedgeo.2007.07.011.

Veevers, J. J., Saeed, A., Belousova, E. A. \& Griffin, W. L. 2005. U-Pb ages and source composition by Hf-isotope and trace-element analysis of detrital zircons in Permian sandstone and modern sand from southwestern Australia and a review of the paleogeographical and denudational history of the Yilgarn Craton. Earth-Science Reviews, 68, 245-279, http://doi.org/10.1016/j.earscirev.2004.05.005.

Veevers, J. J., Belousova, E. A., Saeed, A., Sircombe, K., Cooper, A. F. \& Read, S. E. 2006. Pan-Gondwanaland detrital zircons from Australia analysed for Hf-isotopes and trace elements reflect an ice-covered Antarctic provenance of 700-500 Ma age, TDM of 2.0-1.0 Ga, and alkaline affinity. Earth-Science Reviews, 76, 135-174, http://doi.org/10.1016/j.earscirev.2005.11.001.

Venables, W. N. \& RIPLeY, B. D. 2002. Modern Applied Statistics with S. New York, Springer. 
VERVOORT, J. D. \& PATCHETT, P. J. 1996. Behavior of hafnium and neodymium isotopes in the crust: Constraints from Precambrian crustally derived granites. Geochimica et Cosmochimica Acta, 60, 3717-3733, http://doi.org/10.1016/0016-7037(96)00201-3.

Villaros, A., Buick, I. S. \& Stevens, G. 2012. Isotopic variations in S-type granites: an inheritance from a heterogeneous source? Contributions to Mineralogy and Petrology, 163, 243-257, http://doi.org/10.1007/s00410-011-0673-9.

Viola, G., Henderson, I., Bingen, B., Feitio, P., Thomas, R., Hollick, L. \& Jacobs, J. 2006. A new tectonic framework for northern Mozambique. In: 21 Colloquium on African Geology, Maputo, Mozambique, 3-5 July 2006. Maputo, Mozambique, Associacao Geologica Mineira de Mocambique. Abstract. 168-169.

VORSTER, C. 2013. Laser Ablation ICP-MS Age Determination of Detrital Zircon Populations in the Phanerozoic Cape and Lower Karoo Supergroups (South Africa) and Correlatives in Argentina. PhD thesis, University of Johannesburg, South Africa.

Wareham, C. D., Stump, E., Storey, B. C., Millar, I. L. \& Riley, T. R. 2001. Petrogenesis of the Cambrian Liv Group, a bimodal volcanic rock suite from the Ross Orogen, Transanterctic Mountains. Geological Society of America Bulletin, 113, 360-372, http://doi.org/10.1130/0016-7606(2001)113<0360.

Wasserburg, G. J., Jacobsen, S. B., DePaulo, D. J., McCullochs, M. T. \& Wen, T. 1981. Precise determination of $\mathrm{Sm} / \mathrm{Nd}$ ratios, $\mathrm{Sm}$ and $\mathrm{Nd}$ isotopic abundances in standard solutions. Geochimica et Cosmochimica Acta, 45, 2311-2323, http://doi.org/10.1016/00167037(81)90085-5. 
WiCKHAM, H. 2009. ggplot2: Elegant Graphics for Data Analysis. New York, Springer.

WiEDENBECK, M., ALLÉ, P., ET AL. 1995. 3 natural zircon standars for the U-Th-Pb, Lu-Hf, trace element and REE analyses. Geostandards Newsletter, 19, 1-23, http://doi.org/10.1111/j.1751-908X.1995.tb00147.x.

WiLliaMS, I. S. 2001. Response of detrital zircon and monazite, and their U-Pb isotopic systems, to regional metamorphism and host-rock partial melting, Cooma Complex, southeastern Australia. Australian Journal of Earth Sciences, 48, 557-580, http://doi.org/10.1046/j.1440-0952.2001.00883.x.

WoOdHEAD, J. D. \& HERGT, J. M. 2005. A preliminary appraisal of seven natural zircon reference materials for in situ $\mathrm{Hf}$ isotope determination. Geostandards and Geoanalytical Research, 29, 183-195, http://doi.org/10.1111/j.1751-908X.2005.tb00891.x.

WronkiEWICZ, D. J. \& CondIE, K. C. 1989. Geochemistry and provenance of sediments from the Pongola Supergroup, South Africa: evidence for a 3.0-Ga-old continental craton. Geochimica et Cosmochimica Acta, 53, 1537-1549, http://doi.org/10.1016/00167037(89)90236-6.

Yuhara, M., KAgAmi, H. \& TsuchiYA, N. 2001. Rb-Sr and Sm-Nd systematics of granitic and metamorphic rocks in the Namaqualand Metamorphic Complex, South Africa: Implications for evolution of marginal part of Kaapvaal Craton. National Institute of Polar Research, Special Issue, Memoirs, 55, 127-144.

Zeh, A., Gerdes, A., Klemd, R. \& Barton, J. M. 2007. Archaean to Proterozoic Crustal Evolution in the Central Zone of the Limpopo Belt (South Africa-Botswana): Constraints 
from Combined U-Pb and Lu-Hf Isotope Analyses of Zircon. Journal of Petrology, 48, 16051639, http://doi.org/10.1093/petrology/egm032.

ZeH, A., Gerdes, A., KLemD, R. \& BARTON, J. M. 2008. U-Pb and Lu-Hf isotope record of detrital zircon grains from the Limpopo Belt - Evidence for crustal recycling at the Hadean to early-Archean transition. Geochimica et Cosmochimica Acta, 72, 5304-5329, http://doi.org/10.1016/j.gca.2008.07.033.

Zeh, A., Gerdes, A. \& BARTOn, J. M. 2009. Archean Accretion and Crustal Evolution of the Kalahari Craton - the Zircon Age and Hf Isotope Record of Granitic Rocks from Barberton/Swaziland to the Francistown Arc. Journal of Petrology, 50, 933-966, http://doi.org/10.1093/petrology/egp027.

Zeh, A., Gerdes, A., BARton, J. \& Klemd, R. 2010. U-Th-Pb and Lu-Hf systematics of zircon from TTG's, leucosomes, meta-anorthosites and quartzites of the Limpopo Belt (South Africa): Constraints for the formation, recycling and metamorphism of Palaeoarchaean crust. Precambrian Research, 179, 50-68, http://doi.org/10.1016/j.precamres.2010.02.012.

ZeH, A., Gerdes, A. \& Millonig, L. 2011. Hafnium isotope record of the Ancient Gneiss Complex, Swaziland, southern Africa: evidence for Archaean crust-mantle formation and crust reworking between 3.66 and $2.73 \mathrm{Ga}$. Journal of the Geological Society, London, 168, 953-964, http://doi.org/10.1144/0016-76492010-117.

Zeh, A., Gerdes, A., BARton JR., J. \& KlemD, R. 2012. U-Pb and Hf isotope record of detrital zircons from gold-bearing sediments of the Pietersburg Greenstone Belt (South 
Africa)-Is there a common provenance with the Witwatersrand Basin? Precambrian Research, 204-205, 46-56, http://doi.org/10.1016/j.precamres.2012.02.013.

Zeh, A., Jaguin, J., Poujol, M., Boulvais, P., Block, S. \& Paquette, J. 2013. Juvenile crust formation in the northeastern Kaapvaal Craton at $2.97 \mathrm{Ga}$ - Implications for Archean terrane accretion, and the source of the Pietersburg gold. Precambrian Research, 233, 20-43, http://doi.org/10.1016/j.precamres.2013.04.013.

\section{Figure captions}

\section{Fig. 1.}

Map of the study area (after Marshall \& von Brunn 1999; Marshall 2002) showing outcrops of the Natal Group and the Msikaba Formation with sample localities indicated.

\section{Fig. 2.}

Generalized stratigraphy of the Natal Group (Marshall \& von Brunn 1999; Marshall 2002). Not drawn to scale.

\section{Fig. 3.}

Combined histogram and kernel density estimate plots of all samples stacked according to their (presumed) stratigraphic positions. Ages are given as ${ }^{206} \mathrm{~Pb}-{ }^{238} \mathrm{U}$ ages if equal to or younger than $600 \mathrm{Ma}$, otherwise the ${ }^{207} \mathrm{~Pb}-{ }^{206} \mathrm{~Pb}$ ages have been used. Note that the individual panels use different $y$-axis scaling. Solid curves are KDEs calculated using the algorithm of Botev et al. (2010); dashed curves are gaussian KDEs with bandwidth=30.

\section{Fig. 4.}


Initial $\varepsilon_{\mathrm{Hf}}$ plotted against age for sandstone samples. Contours of a KDE surface for sample SA12/06 drawn at the $95^{\text {th }}$ percentile, and initial $\varepsilon_{\mathrm{Hf}}$ vs. age for granite samples (squares: SA12/24, Mgeni pluton; diamonds: SA13/133, Fafa pluton) are added to all panels. CHUR: chondritic uniform reservoir; DM: depleted mantle.

\section{Fig. 5.}

Initial $\varepsilon_{\mathrm{Hf}}$ plotted against age for the Archaean zircon fraction of the conglomerate samples. Contours of KDE surfaces for comparison data of Archaean age from southern Africa drawn at the $95^{\text {th }}$ percentile are added to each panel; vertical lines: Eldorado Reef, uppermost Central Rand Group (Koglin et al. 2010); horizontal lines: Limpopo Belt (Zeh et al. 2007, 2008, 2009, 2010; Gerdes \& Zeh 2009); dark grey: Murchinson Northern Kaapvaal (Zeh et al. 2009, 2012, 2013); light grey: Barberton (Zeh et al. 2009). CHUR: chondritic uniform reservoir; DM: depleted mantle. 2D KDEs were calculated over an equally spaced 100x100 grid spanning from 2800 to 3800 in the $x$-direction and -5 to 5 in the y-direction using fixed bandwidths of 30 and 1.5 in the $x$ - and y-directions, respectively.

\section{Fig. 6.}

Concordia plot of granite samples. Error ellipses are plotted as 2б. (a) SA12/24. (b)

SA13/133.

\section{Fig. 7.}

Histogram of individual zircon initial $\varepsilon_{\mathrm{Hf}}$ (this study; Spencer et al. 2015) and whole rock $\varepsilon_{\mathrm{Nd}}$ from basement rocks in the Natal Province. Black: $2 \varepsilon_{\mathrm{Nd}}+2$; diagonal lines: $\varepsilon_{\mathrm{Hf}}$ data from Spencer et al. (2015); grey: $\varepsilon_{\mathrm{Hf}}$ data this study. $\varepsilon_{\mathrm{Nd}}$ data obtained from the DateView database (Eglington 2004). $\varepsilon_{\mathrm{Nd}}$ data: Eglington (Unpublished); Thomas \& Eglington (1990); (Thomas 
et al. 1993). $\varepsilon_{\mathrm{Nd}^{-}}$values calculated using a decay constant for ${ }^{147} \mathrm{Sm}$ of $6.54 \times 10^{-12}$ year $^{-1}$ (Lugmair \& Marti 1978) and CHUR parameters: ${ }^{147} \mathrm{Sm} /{ }^{144} \mathrm{Nd}=0.1966$ and ${ }^{143} \mathrm{Nd} /{ }^{144} \mathrm{Nd}=$ 0.512638 (Jacobsen \& Wasserburg 1980; Wasserburg et al. 1981). Crustal array reference line $\left(\varepsilon_{\mathrm{Hf}}=2 \varepsilon_{\mathrm{Nd}}+2\right)$ after Vervoort \& Patchett (1996).

Fig. 8.

Empirical cumulative distribution function plots of Natal Group samples.

\section{Fig. 9.}

Southern Gondwana at $480 \mathrm{Ma}$ (after Torsvik \& Cocks 2013) showing $\varepsilon_{\mathrm{Hf}}$ data from the Saldania Belt (Frimmel et al. 2013), Cape S-type granites (Villaros et al. 2012) Mozambique Belt (Thomas et al. 2010), Ecca Group (Veevers \& Saeed 2007) and Dronning Maud Land (Veevers \& Saeed 2007). For comparison, a $95^{\text {th }}$ percentile contour of the Natal Group data has been added to each panel.

Table 1. Sample coordinates and lithologies

\begin{tabular}{|c|c|c|c|c|}
\hline Sample & Geological unit & Lithology & \multicolumn{2}{|c|}{ Coordinates } \\
\hline SA12/06 & Newspaper Mbr & Sandstone & $30^{\circ} 17^{\prime} 22.50^{\prime \prime} \mathrm{S}$ & $30^{\circ} 45^{\prime} 32.80^{\prime \prime} \mathrm{E}$ \\
\hline SA12/43 & Newspaper Mbr & Sandstone & $28^{\circ} 04^{\prime} 46.38^{\prime \prime} \mathrm{S}$ & $31^{\circ} 52^{\prime} 39.00^{\prime \prime} \mathrm{E}$ \\
\hline SA12/42 & Tulini Mbr & Sandstone & $28^{\circ} 05^{\prime} 00.66^{\prime \prime S}$ & $31^{\circ} 52^{\prime} 39.06 " \mathrm{E}$ \\
\hline $\mathrm{SA} 12 / 20$ & Dassenhoek Mbr & Sandstone & $29^{\circ} 48^{\prime} 21.01^{\prime \prime S}$ & $30^{\circ} 48^{\prime} 13.95^{\prime \prime} \mathrm{E}$ \\
\hline SA $12 / 27$ & Eshowe Mbr & Sandstone & $28^{\circ} 34^{\prime} 41.04^{\prime \prime S}$ & $31^{\circ} 19^{\prime} 10.74^{\prime \prime} \mathrm{E}$ \\
\hline SA12/39 & Ulundi Mbr & Sandstone & $28^{\circ} 05^{\prime} 09.00^{\prime \prime S}$ & $31^{\circ} 52 ' 32.46 " \mathrm{E}$ \\
\hline SA $12 / 29$ & Ulundi Mbr & Conglomerate matrix & $28^{\circ} 32^{\prime} 38.16^{\prime \prime S}$ & $31^{\circ} 08^{\prime} 29.16^{\prime \prime} \mathrm{E}$ \\
\hline SA $12 / 28$ & Ulundi Mbr & Quartzite clast in conglomerate & $28^{\circ} 32^{\prime} 38.16^{\prime \prime S}$ & $31^{\circ} 08^{\prime} 29.16^{\prime \prime} \mathrm{E}$ \\
\hline SA $12 / 24$ & Mgeni pluton & Granite & $29^{\circ} 50^{\prime} 27.00^{\prime \prime} \mathrm{S}$ & $30^{\circ} 42^{\prime} 33.90^{\prime \prime} \mathrm{E}$ \\
\hline SA13/133 & Fafa pluton & Granite & $30^{\circ} 17^{\prime} 36.67^{\prime \prime S}$ & $30^{\circ} 36^{\prime} 54.67 " \mathrm{E}$ \\
\hline
\end{tabular}


Table 2. Results of one-dimensional likeness tests (Satkoski et al. 2013) comparing the Natal Group samples

\begin{tabular}{rrrrrrrr} 
SA12/06 & SA12/43 & SA12/42 & SA12/20 & SA12/27 & SA12/39 & SA12/29 & SA12/28 \\
\hline SA12/06 & 0.68 & 0.83 & 0.92 & 0.77 & 0.66 & 0.03 & 0.00 \\
& SA12/43 & 0.74 & 0.68 & 0.74 & 0.72 & 0.13 & 0.08 \\
& & SA12/42 & 0.85 & 0.84 & 0.73 & 0.03 & 0.00 \\
& & & SA12/20 & 0.77 & 0.68 & 0.03 & 0.00 \\
& & & & SA12/27 & 0.70 & 0.04 & 0.01 \\
& & & & & SA12/39 & 0.14 & 0.11 \\
& & & & & & SA12/29 & 0.79 \\
\hline
\end{tabular}

Table 3. Results of two-dimensional likeness tests (Satkoski et al. 2013) comparing the Natal Group samples

\begin{tabular}{rrrrrrrr} 
SA12/06 & SA12/43 & SA12/42 & SA12/20 & SA12/27 & SA12/39 & SA12/29 & SA12/28 \\
\hline SA12/06 & 0.57 & 0.71 & 0.82 & 0.70 & 0.53 & 0.00 & 0.00 \\
& SA12/43 & 0.62 & 0.57 & 0.56 & 0.47 & 0.06 & 0.08 \\
& & SA12/42 & 0.72 & 0.68 & 0.54 & 0.00 & 0.00 \\
& & & SA12/20 & 0.71 & 0.50 & 0.00 & 0.00 \\
& & & & SA12/27 & 0.60 & 0.01 & 0.01 \\
& & & & & SA12/39 & 0.13 & 0.13 \\
& & & & & & SA12/29 & 0.81 \\
\hline
\end{tabular}

Table 4. P-values for one-dimensional pairwise Kolmogorov-Smirnoff of the Natal Group samples

\begin{tabular}{rrrrrrrr} 
SA12/06 & SA12/43 & SA12/42 & SA12/20 & SA12/27 & SA12/39 & SA12/29 & SA12/28 \\
\hline SA12/06 & 0.00 & 0.12 & 0.88 & 0.11 & 0.00 & 0.00 & 0.00 \\
& SA12/43 & 0.00 & 0.00 & 0.00 & 0.49 & 0.00 & 0.00 \\
& & SA12/42 & 0.25 & 0.78 & 0.00 & 0.00 & 0.00 \\
& & & SA12/20 & 0.16 & 0.00 & 0.00 & 0.00 \\
& & & & SA12/27 & 0.00 & 0.00 & 0.00 \\
& & & & & SA12/39 & 0.00 & 0.00
\end{tabular}


Table 5. H-values for two-dimensional pairwise Kolmogorov-Smirnoff tests of the Natal Group samples

\begin{tabular}{lrrrrrrr} 
SA12/06 & SA12/43 & SA12/42 & SA12/20 & SA12/27 & SA12/39 & SA12/29 & SA12/28 \\
\hline SA12/06 & 1 & 0 & 0 & 0 & 1 & 1 & 1 \\
& SA12/43 & 1 & 1 & 1 & 1 & 1 & 1 \\
& & SA12/42 & 0 & 0 & 1 & 1 & 1 \\
& & & SA12/20 & 0 & 1 & 1 & 1 \\
& & & SA12/27 & 1 & 1 & 1 \\
& & & & SA12/39 & 1 & 1 \\
& & & & & & SA12/29 & 0 \\
\hline
\end{tabular}

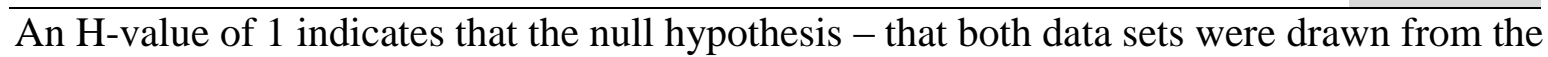
same continuous distribution - should be rejected (i.e. $\mathrm{p}<0.05$ ), the reverse is true for $\mathrm{H}=0$.

Table 6. Results of one-dimensional likeness tests (Satkoski et al. 2013) comparing sedimentary sequences from southern Gondwana including Natal Group sandstones

\begin{tabular}{llrrrrrr} 
NGS & SB & KCCG & EG & DML & EWM & TMGEB & TMGWB \\
\hline NGS & 0.61 & 0.76 & 0.60 & 0.64 & 0.59 & 0.60 & 0.63 \\
& SB & 0.56 & 0.53 & 0.63 & 0.60 & 0.63 & 0.68 \\
& & KCCG & 0.63 & 0.81 & 0.65 & 0.73 & 0.79 \\
& & & EG & 0.70 & 0.78 & 0.66 & 0.65 \\
& & & & DML & 0.71 & 0.83 & 0.80 \\
& & & & & EWM & 0.72 & 0.70 \\
& & & & & & TMGEB & 0.77 \\
& & & & & & & TMGWB
\end{tabular}

NGS: Natal Group sandstones; SB: Saldania Belt (Frimmel et al. 2013); KCCG: Kansa and Cango Caves Groups (Naidoo et al. 2013); EG: Ecca Group (Veevers \& Saeed 2007); DML: Dronning Maud Land (Veevers \& Saeed 2007); EWM: Ellsworth-Whitmore Mountains (Flowerdew et al. 2007); TMGEB and TMGWB: Table Mountain Group Eastern and Western Basin, respectively (Fourie et al. 2010). 
Table 7. Results of two-dimensional likeness tests (Satkoski et al. 2013) comparing sedimentary sequences from southern Gondwana including Natal Group sandstones

\begin{tabular}{|c|c|c|c|c|c|c|c|c|}
\hline NGS & SB & EG & MB & DML & EWM & $\mathrm{P}$ & VS & CG \\
\hline \multirow[t]{9}{*}{ NGS } & 0.41 & 0.46 & 0.42 & 0.51 & 0.45 & 0.21 & 0.13 & 0.34 \\
\hline & SB & 0.44 & 0.39 & 0.38 & 0.47 & 0.27 & 0.12 & 0.43 \\
\hline & & EG & 0.56 & 0.54 & 0.61 & 0.47 & 0.22 & 0.55 \\
\hline & & & MB & 0.51 & 0.42 & 0.24 & 0.16 & 0.36 \\
\hline & & & & DML & 0.45 & 0.36 & 0.16 & 0.41 \\
\hline & & & & & EWM & 0.46 & 0.29 & 0.56 \\
\hline & & & & & & $\mathrm{P}$ & 0.32 & 0.48 \\
\hline & & & & & & & VS & 0.23 \\
\hline & & & & & & & & $\mathrm{CG}$ \\
\hline
\end{tabular}

NGS: Natal Group sandstones; SB: Saldania Belt (Frimmel et al. 2013); EG: Ecca Group (Veevers \& Saeed 2007); MB: Mozambique Belt (Thomas et al. 2010); Dronning Maud Land (Veevers \& Saeed 2007); EWM: Ellsworth-Whitmore Mountains (Flowerdew et al. 2007); P: Patagonia (Uriz et al. 2010); VS: Ventania System (Argentina) (Ramos et al. 2014) CG: Cape Granite (S-type granite) (Villaros et al. 2012). 